African Tax Administration Paper 20

Fiscal and Public Health Impact of a Change in Tobacco Excise Taxes in Ghana

Ama Pokuaa Fenny, Aba Obrumah Crentsil, Christian Kwaku Osei and Felix Ankomah Asante

November 2020 
Fiscal and Public Health Impact of a Change in Tobacco Excise Taxes in Ghana

Ama Pokuaa Fenny, Aba Obrumah Crentsil, Christian Kwaku Osei and Felix Ankomah Asante

African Tax Administration Paper 20

First published by the Institute of Development Studies in November 2020

(C) Institute of Development Studies 2020

ISBN: 978-1-78118-723-4

DOI: $\underline{10.19088 / I C T D .2020 .003}$

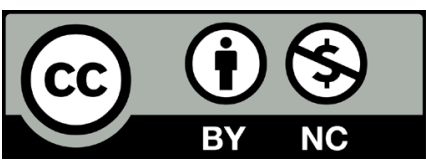

This is an Open Access paper distributed under the terms of the Creative Commons Attribution Non Commercial 4.0 International license, which permits downloading and sharing provided the original authors and source are credited - but the work is not used for commercial purposes. http://creativecommons.org/licenses/by-nc/4.0/legalcode

Available from:

The International Centre for Tax and Development at the Institute of Development Studies, Brighton BN1 9RE, UK

Tel: +44 (0) 1273606261

Email: info@ictd.ac

Web: www.ictd.ac/publication

Twitter: @ICTDTax

Facebook: www.facebook.com/ICTDtax

IDS is a charitable company limited by guarantee and registered in England

Charity Registration Number 306371

Charitable Company Number 877338 


\title{
Fiscal and Public Health Impact of a Change in Tobacco Excise Taxes in Ghana
}

\author{
Ama Pokuaa Fenny, Aba Obrumah Crentsil, Christian Kwaku Osei and Felix \\ Ankomah Asante
}

\section{Summary}

This working paper predicts the fiscal and public health outcomes from a change in the excise tax structure for cigarettes in Ghana. More than 5,000 people are killed by diseases caused by tobacco every year in Ghana (Tobacco Atlas 2018). Currently the country has a unitary tax administration approach, with a uniform ad valorem tax structure on all excisable products, including tobacco. However, the ECOWAS directive on tobacco control, in line with the WHO Framework Convention on Tobacco Control (WHO 2003), recommends a simple tax structure - using a mixed excise system with a minimum specific tax floor to overcome the limitations of an ad valorem system on tobacco products, especially cigarettes. The study therefore simulates mixed tax policy interventions, and assesses their effect on government revenue and public health relative to the current ad valorem tax system. Primary data collection of tobacco prices in three geographical zones of the country was conducted in February 2020, across both rural and urban localities. This was supported with secondary data from national and international databases.

Based on the assumption that Ghana adopts a mixed tax structure, the simulation shows that, if the government imposes a specific excise tax of GH\$4.00 (US\$0.80) per pack in addition to the current ad valorem rate of 175 per cent of the CIF value, the average retail price of a cigarette pack would increase by 128 per cent, cigarette consumption decrease by 27 per cent, tobacco excise tax revenue increase by 627 per cent, and overall tobaccorelated government tax revenue increase by 201 per cent. ${ }^{1}$ Additionally, there would be significant declines in smoking prevalence (3.3\%), smoking intensity $(1,448$ cigarettes per year), and 3,526 premature smoking-related deaths would be avoided. The paper advocates for a strong tax administration and technical capacity, with continuous commitment by the government to adjust the tax rate in line with the rate of inflation and per capita income growth.

Keywords: tobacco consumption; cigarette prices; tax administration; government revenue; public health; simulation models; Ghana.

Ama Pokuaa Fenny is a Senior Research Fellow with the Institute of Statistical, Social and Economic Research (ISSER), University of Ghana. Her research areas include health financing, strengthening health systems, integration of evidence-based policies into service delivery systems in Africa, social protection and gender-based analysis. She has a PhD in Health Economics from the Department of Public Health, Aarhus University, Denmark.

Aba Obrumah Crentsil is a Research Fellow at the Institute of Statistical, Social and Economic Research (ISSER), University of Ghana. Her research focuses on a broad range of themes in development studies relating to environmental health, human geography, human health and sustainable cities. She has a PhD in Development Studies from the Kwame Nkrumah University of Science and Technology, Kumasi, Ghana.

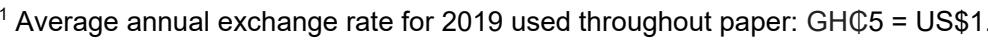


Christian Kwaku Osei is an Economist with research interests in health economics, public finance and energy economics. He has an MPhil in Economics from the University of Ghana.

Felix Ankomah Asante is a Professor at the Institute of Statistical, Social and Economic Research (ISSER), University of Ghana. He is Pro Vice-Chancellor (Research, Innovation and Development) of the University of Ghana, and was Director of ISSER from August 2013 to July 2019. His research focuses on a broad range of themes in development economics relating to household food security, decentralisation and provision of public goods and services, health issues, and climate change. 


\section{Contents}

Summary 3

Acknowledgements 6

$\begin{array}{lc}\text { Abbreviations } & 6\end{array}$

1 Introduction $\quad 7$

2 Tobacco taxation, government revenue and tobacco consumption 8

$3 \quad$ Tobacco taxation in Ghana 9

$\begin{array}{ll}\text { 3.1 Rationale for a uniform mixed tax system } & 10\end{array}$

$4 \quad$ Methods and data sources $\quad 11$

4.1 Study design and data collection $\quad 11$

4.2 Simulation models on tobacco taxation 12

4.3 Fitting the TETSiM model to the Ghanian context 12

4.3.1 Model specification 13

$\begin{array}{lll}4.4 & \text { Data } & 15\end{array}$

$\begin{array}{lll}4.4 .1 & \text { Assumptions underlying key parameters } & 16\end{array}$

$\begin{array}{lll}4.5 & \text { Scenario simulation (proposed policy interventions) } & 17\end{array}$

$5 \quad$ Results $\quad 18$

$\begin{array}{lll}5.1 & \text { Cigarette brands and prices } & 18\end{array}$

$\begin{array}{lll}5.2 & \text { Simulation results } & 18\end{array}$

5.2.1 Fiscal effects 19

5.2.2 Demographic and public health effects 21

$\begin{array}{ll}5.2 .3 \text { Discussion } & 22\end{array}$

$\begin{array}{lll}5.2 .4 & \text { Limitations } & 23\end{array}$

$6 \quad$ Conclusion and recommendation $\quad 24$

$\begin{array}{ll}\text { Appendices } & 25\end{array}$

$\begin{array}{ll}\text { References } & \mathbf{3 0}\end{array}$

Tables

Table 1

Table 2

Table 3

Table 4

Table 5

Table 6

Background to tobacco tax structure and tax rates in Ghana 9

Trend in excise tax structure for cigarettes $\quad 11$

Key baseline data and sources $\quad 15$

Possible policy interventions $\quad 17$

Overview of cigarette price data in Ghana 18

Simulation results of imposing a uniform mixed tax and uniform specific tax system on cigarettes (fiscal effects) 19

Table $7 \quad$ Simulation results of demographic/public health effects (with

2-year projection) 21 


\section{Acknowledgements}

The authors would like to acknowledge funding from the International Centre for Tax and Development (ICTD) of the Institute of Development Studies. The authors would also like to acknowledge the support of Professor Corné van Walbeek, Dr. Hana Ross and Dr. Laura Rossouw of the Research Unit on the Economics of Excisable Products (REEP), University of Cape Town for their initial comments and guidance at the proposal stage. Thanks to all who supported our participation in the UCT Knowledge Hub workshop on tobacco tax modelling in Cape Town, South Africa.

\section{Abbreviations}

$\begin{array}{ll}\text { CIF } & \text { Cost, Insurance and Freight } \\ \text { ECOWAS } & \text { Economic Community of West Africa States } \\ \text { FAO } & \text { Food and Agriculture Organisation } \\ \text { GDHS } & \text { Ghana Demographic and Health Survey } \\ \text { GDP } & \text { Gross Domestic Product } \\ \text { GRA } & \text { Ghana Revenue Authority } \\ \text { LMIC } & \text { Low- and middle-income countries } \\ \text { MOF } & \text { Ministry of Finance } \\ \text { NCI } & \text { National Cancer Institute, USA } \\ \text { SSA } & \text { Sub-Saharan Africa } \\ \text { TETSiM } & \text { Tobacco Excise Tax Simulation Model } \\ \text { VAT } & \text { Value added tax } \\ \text { WHO FCTC } & \text { WHO Framework Convention on Tobacco Control }\end{array}$




\section{Introduction}

Cigarettes have generally become less affordable in developed economies over time, with increased taxes and small increases in income, but more affordable in developing countries, where there have been minimal changes in taxes (Chaloupka et al. 2019). Studies by the WHO suggest that 80 per cent of the world's smokers live in low- and middle-income countries (LMICs), and more than 80 per cent of those dying from tobacco-related diseases will be from those countries by 2030 (Ho et. al. 2018). In Ghana, more than 5,000 people are killed by diseases caused by tobacco every year (Tobacco Atlas 2018). Recent estimates show that there are more than 5,000 children (10-14 years old) and 804,000 adults (15+ years old) in Ghana who use tobacco every day (Tobacco Atlas 2018). Currently all cigarettes consumed in Ghana are imported, mainly from Nigeria, after the closure of the British American Tobacco manufacturing plant in 2006. Although cigarettes remain the commonest form of tobacco used in Ghana, other forms of tobacco are also used - pipe smoking (shisha), chewing, sniffing, and smokeless tobacco (tawa), which is often used among young people (Singh et al. 2020).

All rounds of the Ghana Demographic and Health Survey (GDHS) show wide gender disparity, with male smokers far outnumbering female smokers. Despite the fragmented data, the prevalence of smoking among adults $\left(15^{+}\right)$is estimated at 5.4 per cent and 0.1 per cent for males and females respectively (WHO 2019), with regional and socioeconomic disparities (CRES 2014; Singh et al. 2020). In particular, the northern regions and poorer sections of society have the highest prevalence rates (CRES 2014) - the prevalence rates amongst male adults in the Northern, Upper East and Upper West regions are 9.6 per cent, 10.3 per cent and 8.6 per cent respectively (GDHS 2014a). The economic cost of smoking in Ghana is estimated to be about GHC97 million (Tobacco Atlas 2018). This includes both direct costs relating to healthcare, as well as indirect costs relating to lost productivity due to early mortality and morbidity.

The effectiveness of increasing excise tax as a tool to reduce tobacco use depends on how the tax increase affects the retail price of the product (IARC 2011; Linegar and van Walbeek 2018; van Walbeek 2010). Global tobacco consumption and taxation policies have been strongly influenced by the WHO Framework Convention on Tobacco Control (WHO FCTC). Specifically, Article 6 of the WHO framework recognises price and tax measures as effective mechanisms to decrease tobacco demand. The guidelines of Article 6 encourage the use of taxation as part of a comprehensive strategy for tobacco control. However, tobacco tax rates in many LMICs are currently low, and demand for tobacco products is relatively inelastic (Kostova et al. 2013). Therefore, it is envisaged that many countries could increase government revenue significantly through tobacco taxation. Tobacco taxation creates a winwin policy for governments across the world - creating the fiscal space to raise revenue to finance development programmes, while improving public health by decreasing tobacco use.

For taxes to have maximum impact, it is widely suggested that either a specific tax system or a specific mixed excise system be implemented to allow for inflation and economic growth (Chaloupka et al. 2019; World Bank 2018a). In both cases, taxes (especially the specific component) have to be increased regularly in order to push retail prices up and make cigarettes less affordable. Pure ad valorem is faced with complexities, including tax evasion and avoidance, low revenue and high administrative costs (Ho et al. 2018; WHO 2010; World Bank 2018a). Ghana's current tax system for tobacco products is purely uniform ad valorem. Although Ghana applies one of the highest rates in the sub-region, cigarettes have become more affordable over time, particularly between 2008 and 2018 (WHO 2019), with sales 
prices controlled mainly by the tobacco industry (CRES 2014). The industry's ability to manipulate prices adversely affects the impact of tax regulation.

There are few empirical studies on tobacco taxation in developing countries, compared to a vast number in developed countries (Akanonu et al. 2018; Azomahou et al. 2019; Singh et al. 2020; Vellios et al. 2018). Most of the research in this field in Ghana has focused on smoking and smoking-related determinants, the effect of the cigarette price, smoking prevalence, and general assessment of tobacco regulations in the country (Owusu-Dabo et al. 2009; NketiahAmponsah et al. 2018; Logo et al. 2020). This study aims to fill the gap in the literature, and provide a case for advocating more stringent policy directives to reduce tobacco consumption.

\section{Tobacco taxation, government revenue and tobacco consumption}

Low- and middle-income countries (LMICs) are more affected by cigarette addiction than other countries (Chaloupka et al. 2019; NCl and WHO 2016). However, despite the addictiveness of nicotine, an increase in tobacco prices does reduce tobacco consumption (Chaloupka et al. 2000; IARC 2011). Tobacco taxation modelling across various countries has shown that tobacco taxes are regarded as the best tool for reducing cigarette consumption (Goodchild et al. 2016; La Foucade et al. 2018; Verguet et al. 2015; van Walbeek 2014; World Bank 2018b; Zheng and Huang 2015). According to Chaloupka et al. (2000), cigarette demand in lower-income countries is at least twice as sensitive to price as demand in higher-income countries. Taxes on tobacco and tobacco products therefore form an important component of government revenue in many countries, especially in emerging economies (Azomahou et al. 2019; Chaloupka et al. 2012).

A wide range of literature on tobacco taxation has focused on industrialised economies in the global North. However, we observe a growing number of studies in many developing countries, especially in Asia, the Gulf, Pacific, Caribbean Islands and Latin America (Barber et al. 2008; Chaloupka et al. 2012; Goodchild and Zheng 2018; Ho et al. 2018; Zheng and Huang 2015). Additionally, there are a number of studies on tobacco taxation across subSaharan Africa (SSA) and South Africa (CRES 2014; Linegar and van Walbeek 2018; van Walbeek 2010; Vellios et al. 2018).

Most studies in SSA have been modelled under ex-post analysis, with few giving an empirical analysis and predictions of fiscal and public health implications of tax changes. Modelled simulations by Akanonu et al. (2019a) on the public health and fiscal effects of tax change in Nigeria show that a significant increase in excise tax on cigarettes, alongside a change to a specific excise tax system, yields the most significant gains in public health (measured by less cigarette consumption and smoking prevalence), and fiscal revenue (measured by increase in excise tax and other government revenue). Given Nigeria's ad valorem tax structure, this study was constrained to specific tax simulations, with limited comparative analysis with a mixed system. Model simulations by van Walbeek (2010) across selected LMICs show that a 20 per cent increase in excise tax decreases cigarette consumption and industry revenue by 5 per cent, and increases excise tax revenue by 14 per cent, if there is no change in net-of-tax price. The study further argues that the tobacco industry has an incentive to reduce the net-of-tax price in response to an ad valorem excise tax increase, subverting the fiscal and public health benefits of the tax increase. 
The modelling on tobacco taxation in Ghana by van Walbeek (2014) was limited to fiscal effects. Therefore, this study builds on the work by van Walbeek (2014), making four key contributions:

1. Our modelling provides an ex ante analysis of the likely impact of a change in tobacco tax based on the prevailing average market prices in Ghana.

2. We explore the dynamics of the specific mixed tax system relative to the specific and the current ad valorem.

3. We model the predicted effects of critical indicators of health outcomes in addition to the significant impact on government revenue.

4. Our study provides further justification of the need for tax structure changes that have a relatively higher impact than the current ad valorem.

This study goes further to address the health impacts of the proposed tax changes - such as the impacts on smoking prevalence, smoking intensity, as well as the number of premature deaths averted.

\section{Tobacco taxation in Ghana}

Article 6.1 of the WHO FCTC requires all parties to the convention to recognise that price and tax measures are an effective means of reducing tobacco consumption by various segments of the population, in particular young persons' (WHO 2003 Annex: 125 ). The government acknowledges the imposition of excise tax on tobacco products as a necessary measure to curb the harmful effects of tobacco products on public health (MoH and GHS 2010). Prior to 2007, Ghana imposed a flat ad valorem rate of 140 per cent (of CIF value) on all tobacco products. In 2007, the taxation structure was changed to a differentiated specific excise tax for cigarettes - the rate varied depending on the type of cigarette imported (see Table 1). However, there was a decrease in the total tax revenue from non-petroleum excisable products two years after this tax structure was introduced, mainly driven by less revenue from alcoholic beverages. Revenue from tobacco taxes actually increased. Unfortunately, with the reduction in total revenue, coupled with the prevailing tax administrative approach, the government reverted to the previous tax regime in 2010 . This was a flat ad valorem rate of 140 per cent of CIF value, which was increased to 150 per cent in 2014, and increased further to its current rate of 175 per cent in 2015.

Table 1 Background to tobacco tax structure and tax rates in Ghana

\begin{tabular}{|c|c|c|}
\hline Time period & Tax structure & Tax rate \\
\hline Before 2007 & Ad valorem & $140 \%$ \\
\hline $2007-2009$ & Specific & $\begin{array}{l}\text { Premium cigarettes (GHC0.0275 per stick); } \\
\text { High quality (GHC0.0235 per stick); } \\
\text { Medium quality (GHC0.0175 per stick); } \\
\text { Low quality (GHФ0.0100 per stick) }\end{array}$ \\
\hline 2010 & Ad valorem & $140 \%$ \\
\hline 2014 & Ad valorem & $150 \%$ \\
\hline 2015 - date & Ad valorem & $175 \%$ \\
\hline
\end{tabular}

Source: MoH and GHS (2010); Parliament of Ghana (2015)

The current CIF value is, however, very low compared to the retail price. Although the ad valorem rate is higher in SSA and above the ECOWAS minimum ad valorem benchmark of 50 per cent, when converted Ghana's excise tax as a percentage of cigarette prices is comparatively low in Africa (ECOWAS Protocol 2017; Parliament of Ghana 2015). It is 
estimated that excise tax as a percentage of the retail price of the most sold brand of cigarettes is about 16 per cent, while total tax (excise + import duty + VAT + other levies) is 31.3 per cent of the retail price (Parliament of Ghana 2015). Ghana's excise tax rate on tobacco products, currently 16 per cent, is also below the WHO-recommended minimum threshold of 70 per cent ( $\mathrm{NCl}$ and $\mathrm{WHO} 2017$ ). According to the World Bank, an ad valorem excise tax system is faced with complexities - particularly in determining the tax base, which is highly influenced by manufacturers (World Bank 2018a). This affects the retail price, and could also result in tax avoidance, inefficiency in tax compliance (administrative costs), and loss of expected revenue when taxes are increased (World Bank 2018a).

\subsection{Rationale for a uniform mixed tax system}

Ghana has adopted a tax policy approach whereby a uniform tax policy is imposed on all non-petroleum excisable products - a single tax policy is imposed on all tobacco, alcoholic and non-alcoholic drinks, and there is no differentiation in the tax structure for any nonpetroleum excisable products. However, with the tobacco industry having control over cigarette sales in Ghana, the CIF value is increasingly manipulated by tobacco importers (van Walbeek 2014). According to Nana (2014), despite existing literature showing a significant impact of specific excise taxes, the characteristics of the tobacco industry in developing countries are heterogeneous.

Given the current tax administration policy, this study simulates various mixed tax structure systems for Ghana that can be used as a basis for further policy intervention. Though the current ad valorem tax structure preserves the real value of the excise as prices increases, it:

- is typically susceptible to undervaluation

- encourages price reductions

- disincentivises costly 'quality' improvements due to the multiplier effect, and

- encourages 'trading down' in favour of cheaper tobacco products, thereby reducing the health benefits (WHO 2010).

On the other hand, imposing specific excise taxes tends to increase consumer prices relatively more than ad valorem excises, and hence leads to a relatively higher reduction in consumption.

Though Ghana applies one of the highest rates (175\% ad valorem) in the ECOWAS region, cigarettes have become more affordable over time (ICTD 2020). Affordability measures the price of cigarettes relative to income. Estimates from WHO (2019) show that cigarettes in Ghana became more affordable between 2008 and 2018. In the report, the percentage of GDP per capita needed to purchase 2,000 cigarettes of the most sold brand in Ghana was 8.22 per cent in 2016, and declined to 5.96 per cent in 2018. However, due to an improved standard of living and manipulation of the CIF value by tobacco importers, the ad valorem excise system is now less popular (CRES 2014). The yield from cigarette excise taxation is relatively low (van Walbeek 2014) - the CIF value reported by importers is usually very low, and a high tax percentage on a low base amount yields only a modest amount of revenue.

In view of this, Article 6 of the recent ECOWAS directive on tobacco control in SSA requires member states to subject tobacco products to an excise duty, which must include an ad valorem duty and a specific duty (ECOWAS Protocol 2017). Specifically, it requires member states to enforce a minimum of 50 per cent ad valorem, and a specific excise equivalent to US $\$ 0.02$ per stick of cigarette, cigar and cigarillos, translating to about US\$0.40 (GHđ2.00) for a typical 20-cigarette pack in Ghana. Further, recommendations by the National Cancer Institute $(\mathrm{NCl})$ and $\mathrm{WHO}$ show that a minimum uniform specific excise tax is required. 
However, if a country is already implementing an ad valorem system, then the country may add a uniform specific element to it, as these systems have considerable advantages over purely ad valorem systems (IARC 2011; NCl and WHO 2017).

World Bank (2018a) shows that relatively few countries rely on ad valorem excises for maximum tax impact. An assessment by WHO (2010) shows that only 47 of 182 countries that impose some form of tobacco tax were able to meet the World Bank's minimum yardstick (i.e. tax component accounting for two-thirds of cigarette retail price). Of these 47 countries, 30 implement a mixed excise system, 7 an ad valorem excise, and the remaining 10 countries a specific excise (WHO 2010).

We observe that the number of countries that implemented a mixed tax system between 2010 and 2018 increased by 27 per cent, while countries with specific tax systems increased by 20 per cent. The number of countries operating an ad valorem system reduced by 22 per cent over the same period (Table 2). In line with WHO FCTC, it is recommended that tobacco products should be taxed in a comparable way to minimise the incentive to shift to cheaper products or product categories (WHO 2010). As a result, a uniform mixed tax system, as opposed to tiered or differentiated excise tax structure, should be adopted. The study by Chaloupka et al. (2010) provides strong evidence to show that the price gap between premium and low-priced brands is larger in countries with a higher share of ad valorem.

Table 2 Trend in excise tax structures for cigarettes

\begin{tabular}{|l|l|l|l|}
\hline Type of tobacco tax structure & Number of countries & & $\begin{array}{l}\text { Countries that met World Bank's } \\
\mathbf{2 0 1 0} \text { threshold }\left(\mathbf{2}_{3} \text { yardstick) }\right.\end{array}$ \\
\hline & $\mathbf{2 0 1 0}$ & $\mathbf{2 0 1 8}$ & \\
\hline Purely ad valorem system & 60 & 47 & 7 \\
\hline Purely specific excise system & 55 & 66 & 10 \\
\hline Mixture of both excises & 48 & 61 & - \\
\hline No excise & 19 & 19 & - \\
\hline Total & $\mathbf{1 8 2}$ & $\mathbf{4 7}$ \\
\hline
\end{tabular}

Source: WHO (2010); World Bank (2018a)

\section{Methods and data sources}

\subsection{Study design and data collection}

The study design was cross-sectional, using quantitative research methods. The survey was conducted in February 2020 in selected enumeration areas in three geographical zones Southern (Greater Accra and Central Regions); Middle (Ashanti Region) and Northern (Northern Region) (see Appendix 2 for a summary of fieldwork). Primary data collected included cigarette prices and brands from wholesalers and retailers of tobacco products, classified into big shops/supermarkets, small shops and vendors.

When collecting pricing data, fieldworkers were required to visit all retail outlets and street vendors where cigarettes were sold in the selected areas. Fieldworkers recorded the price of as many cigarettes as possible, and took photographs of all recorded prices using their smartphones. Fieldworkers then added the price, and other information such as brand and sub-brand of the cigarette, date and address, on an Excel spreadsheet. The data from all fieldworkers was combined and used for analysis. 


\subsection{Simulation models on tobacco taxation}

Simulation models are useful to predict and describe complex social phenomena. They are particularly helpful in understanding policies directed at influencing tobacco use. Tobacco tax models vary in focus, complexity and scope, which could either be economic or epidemiological. Model complexity could encompass the data requisites and sampling frame, whereas the scope could be expanded to accommodate the impact of other tobacco control measures beyond tax. Examples of standardised tax models include SimSmoke, TaxSim and TETSiM.

The SimSmoke tobacco control simulation model developed by Levy (2010) is a discretetime first-order Markov model that projects smoking prevalence and deaths attributed to smoking in the absence of policy change, and then estimates the effect of tobacco control policies on those outcomes. It has been designed to consider the impact of numerous tobacco control interventions, such as smoke-free spaces, advertising and marketing restrictions, pictorial health warnings and excise tax. It is considered as a 'non-economic' model, more focused on epidemiology (premature deaths averted; disability-adjusted life years, and requires a lot of detailed data - though simplified versions exist. To address some of the shortcomings of SimSmoke, the TaxSim model, initially developed by WHO in 2012, focuses strongly on the economic aspects, especially relating to tax increases (WHO 2018). This model caters for many eventualities and tax structures, which makes it very powerful and robust (Goodchild et al. 2016).

TETSiM is a simulation tool used by advocates of tobacco control and government officials to consider the impact of changes in tobacco excise taxes on a number of outcomes. The mathematical model that forms the basis of TETSiM is generic, and can be calibrated to a variety of countries.

\subsection{Fitting the TETSiM model to the Ghanaian context}

The Tobacco Excise Tax Simulation Model (TETSiM) was used for this study. Using TETSiM, we calculated the effect of three possible changes (policy interventions) in Ghana's tobacco tax structure on key policy outcomes. The estimated outcomes are:

- Government revenue. The total revenue generated from imposition of the tax policy, including excise tax, VAT and tobacco levy revenue (ECOWAS and import duty)

- Smoking intensity. Number of cigarettes smoked per person per period of time

- Smoking prevalence. Proportion of people smoking within adult population

- Excise tax burden. Excise tax as a percentage of retail price

- Reduction in number of cigarettes consumed as a result of the policy intervention

- Number of lives saved as a result of the policy intervention.

Tobacco tax modelling for all governmental policies aims to analyse the likely impact of tax changes on government revenue and public health. The tax models help to support the government's budget process, and serve as a good basis for policy decision-making. First developed and published by van Walbeek (2010), and later adopted by researchers from the University of Cape Town under the Economics of Tobacco Control Project, the aim of the spreadsheet model was to help users from countries with very limited data to get reasonable predictions of the impact of a tax increase for a specific tax, ad valorem tax or mixed tax.

The model estimates the quantitative impact of a change in excise tax on a number of variables: cigarette price, cigarette consumption, smoking prevalence, excise tax revenue, industry revenue and smoking-related mortality. The model contains the following inputs: 
retail price, general sales tax (or VAT rate), excise tax rate, estimate of price elasticity of demand, adult population (15+), smoking prevalence and total cigarette consumption.

To fit the model to the Ghanaian context, the following assumptions were made:

- The cigarette market is assumed to be fairly homogenous, with limited variation in price around the average

- While cigarette smuggling may exist at the outset, it is assumed that an increase in excise tax does not increase cigarette smuggling

- The change in excise tax is assumed to be fully passed on to smokers

- The model does not assume that the government or tobacco industry aims to optimise some quantity - for example, excise tax revenue or industry profit, respectively. Given an initial situation, it simply considers what will happen if the government changes the excise tax.

The model begins with the retail price (RP) of cigarettes. The retail price is the pivotal point for tobacco control policy. The retail price is the sum of the excise tax, a general sales tax (all other taxes including value added tax, ECOWAS levy and import levy), and net-of-tax price (NTP) or wholesale/retail price. The government controls the different taxes, while the tobacco industry and broader value chain (including primary producers, manufacturers, importers, logistical companies, wholesalers and retailers) control the net-of-tax price (Akanonu et al. 2019). The model separates each brand of the product into market segments based on price. The general segments assumed are premium, medium and low. The contribution of each segment to the average retail price is weighted by its share of the tobacco market in the economy.

To determine the desired output indicators, we add input values for the following variables:

1. Total cigarette consumption

2. Value added tax (VAT)

3. Excise tax

4. ECOWAS levies and import duty

5. Cost, insurance and freight (CIF)

6. Adult population (15+)

7. Current smoking prevalence

8. Percentage decrease in consumption resulting from smoking prevalence

9. Percentage of quitters who avoid premature death

10. Price elasticity of demand

11. Cross-price elasticity of demand (to lower price category).

The base year was 2020, with initial fiscal and public health forecast estimations for 2021. In addition to public health effects, the estimated values for various indicators in 2021 are set by the model as base values for the predicted estimations in 2022.

\subsubsection{Model specification}

The retail price for the base year is set at the outset as $\mathrm{RP}_{\text {base }}$. For our model, the retail price for the next period $\left(\mathrm{RP}_{\text {new }}\right)$ is computed as: 
$R P_{\text {new }}^{2}=$ CIF price $_{\text {new }}+$ ECOWAS Duty ${ }_{\text {new }}+$ Excise Tax $_{\text {new }}+$ Wholesale/retail Mark-up $p_{\text {new }}+$

$V A T_{\text {new }}$

However, each input variable for the retail price for each brand market segment is computed as:

CIF price new $=$ CIF price $_{\text {base }}{ }^{*}\left(1+\right.$ percentage change in the $\left.\mathrm{CIF}_{\text {base }} / 100\right)$

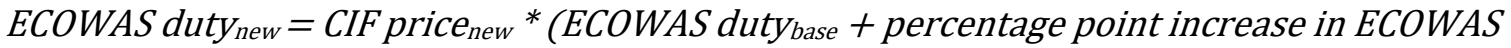
dutybase)/100

Excise tax $_{\text {new }}=$ ad $_{\text {valorem }}$ new $^{*}\left(\right.$ CIF $_{\text {price }}$ new + ECOWAS duty $\left._{\text {new }}\right)+$ specific excise tax $_{\text {new }}$

Wholesale $/$ retail mark-up $p_{n e w}=$ wholesale $/$ retail mark-up base $^{*}$ (percentage point change in the wholesale/retail mark-up base +1 )

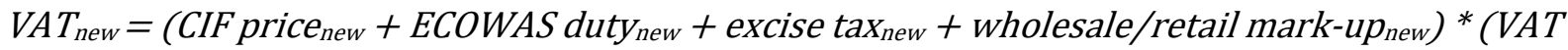
rate $\left._{\text {base }} / 100\right)$

Further, the excise tax burden for each time period for each market segment is computed as:

Excise burden $=($ excise tax amount $/$ retail price $) * 100$

Additionally, in terms of revenue generated from tobacco consumption for each brand market segment, we have:

Total government revenue $=$ tobacco levy revenue + excise tax revenue + VAT revenue

In a breakdown of the total government revenue, we have,

Tobacco levy revenue $=$ total tobacco consumption * ECOWAS duty

Excise tax revenue $=$ total tobacco consumption * excise tax

VAT revenue $=$ total tobacco consumption ${ }^{*}$ VAT rate

Similarly, for expenditure generated from tobacco consumption, we have

Total expenditure $=$ total tobacco consumption ${ }^{*}$ retail price

A decrease in total cigarette consumption can come about in two ways: fewer smokers (a decrease in smoking prevalence), or less cigarettes smoked by smokers (a decrease in smoking intensity) (van Walbeek 2010). The model computes the percentage change in smoking prevalence and smoking intensity given the specification of proportional magnitudes of the individual components.

\footnotetext{
$2 \quad \mathrm{RP}_{\text {new }}$ is new retail price as a result of a tax policy change. This is computed taking into consideration the base year values and the market share of each brand segment for each individual input variable.

3 ECOWAS duty includes ECOWAS levy and import duty.
} 
Therefore, in terms of the demographic and public health perspective of tobacco consumption, we have:

Smoking intensity (per year) $=$ number of cigarettes smoked / number of smokers

Smoking prevalence (of adult population) $=$ [number of smokers $/$ adult population $(15+)]^{*}$ 100

Given the initial smoking prevalence, the size of the adult population and the percentage of decrease in cigarette consumption as a result of decrease in smoking prevalence, the model calculates the number of people who are expected to quit smoking and the number that will be saved from a premature tobacco-related death.

Hence, we compute as follows:

Number of premature deaths avoided $=$ (number of smokers sase - number of smokers sew $) *$ (percentage of quitters who avoided premature death)

Where,

Number of smokers $_{\text {base }}=$ smoking prevalence $_{\text {base }} *$ adult population $(15+)$

Number of smokers new $=$ number of smokers base $^{*}[1+($ percentage change in consumption $/ 100)$ * percentage of decrease in consumption due to decrease in smoking prevalence / 100]

\subsection{Data}

Primary data included the cigarette prices and brands collected from wholesalers and retailers of tobacco products during the survey. The price bands for the various market segments were adopted and modified from Vision for Alternative Development's report on Ghana's Implementation of the FCTC (VALD 2010). Other secondary data needed was sourced from international databases due to a lack of these in national databases. A summary of key baseline data and their sources are presented in Table 3.

Table 3 Key baseline data and sources

\begin{tabular}{|c|c|c|c|}
\hline Item & Baseline data & Year & Source \\
\hline $\begin{array}{l}\text { VAT rate (including National Health Insurance } \\
\text { Levy and Ghana Education Trust Fund Levy) }\end{array}$ & $17.5 \%$ & 2017 & GRA \\
\hline Ad valorem & $175 \%$ & 2015 & $\begin{array}{l}\text { Excise Duty (Amendment) } \\
\text { Act } 2015\end{array}$ \\
\hline Import duty & $20 \%$ & 2018 & VALD \\
\hline Other taxes & $\begin{array}{l}\text { (ECOWAS } 0.5 \%, \\
\text { Econ Dev and } \\
\text { Investment Fund } \\
0.5 \% \text {, processing fee } \\
1 \% \text {, export import } \\
\text { fund (EXIM) } 0.75 \% \text { ) }\end{array}$ & 2019 & WHO \\
\hline Adult population (15+) in millions & 19.5 & $\begin{array}{l}2020 \\
\text { estimates }\end{array}$ & UN \\
\hline Smoking prevalence & $3.8 \%$ & $\begin{array}{l}2017 \text { (age- } \\
\text { standardised) }\end{array}$ & WHO \\
\hline
\end{tabular}




\begin{tabular}{|c|c|c|c|}
\hline $\begin{array}{l}\text { Percentage decrease in cigarette due to } \\
\text { decrease in smoking prevalence }\end{array}$ & $50 \%$ & & $\begin{array}{l}\text { Chaloupka et al. 2019; } \\
\text { TETSiM } 2010\end{array}$ \\
\hline $\begin{array}{l}\text { Percentage quitters who avoid premature } \\
\text { death }\end{array}$ & $35 \%$ & & $\begin{array}{l}\text { Barber et al. 2008; TETSiM } \\
\text { 2010) }\end{array}$ \\
\hline $\begin{array}{l}\text { Average cigarette retail price per pack } \\
\text { (domestic premium) }\end{array}$ & $\mathrm{GH} \nsubseteq 9.38$ & 2020 & \multirow[t]{3}{*}{ Primary data from survey } \\
\hline $\begin{array}{l}\text { Average cigarette retail price per pack } \\
\text { (domestic medium) }\end{array}$ & GHÆ6.84 & 2020 & \\
\hline $\begin{array}{l}\text { Average cigarette retail price per pack } \\
\text { (domestic economy) }\end{array}$ & GH\$5.12 & 2020 & \\
\hline Total cigarette consumption (million packs) & 65 & 2017 & GlobalData (2019) \\
\hline
\end{tabular}

\subsubsection{Assumptions underlying key parameters}

When conducting the impact analysis of tax policies, TETSiM initially constructs a description of the existing market and tax situation for cigarettes at a comprehensive level, by brand and market segment. This creates a baseline against which the impact of taxation strategies on key market parameters can be measured. TETSiM performs the analysis on the following assumptions:

Price elasticity $\left(\varepsilon_{p}<0\right)$. We assume three price elasticities of cigarette demand for each market segment. Drawing from the study by La Foucade et al. (2018a), we assume that smokers of premium brands have a price elasticity similar to that of smokers in high-income countries at $\varepsilon_{p 1}=-0.2$ to -0.4 ; smokers of economy brands (low) have a price elasticity similar to that of low-income countries at $\varepsilon_{p 3}=-0.8$ to -1.0 ; and smokers of mid-price brands have a price elasticity that is an average of the other groups at $\varepsilon_{p 2}=-0.5$ to -0.7 . In the absence of price elasticity estimates for Ghana, this paper estimates the average of the interval range for each brand segment. Hence, premium (-0.3), economy $(-0.9)$ and medium (-0.6). Economyand medium-quality cigarettes are typically consumed by poorer consumers who are usually more price-sensitive than less poor consumers. Premium cigarettes, on the other hand, are typically consumed by more well-to-do consumers - the demand for these cigarettes is expected to be less price-elastic.

Change in cigarette consumption. Given nicotine addiction, smokers fully respond to higher prices over time. Reduction in cigarette consumption as a result of price increases is attributable to 50 per cent decrease in prevalence and 50 per cent decline in smoking intensity (i.e. the number of cigarettes smoked by continuing smokers) (Chaloupka et al. 2019; NCl and WHO 2016; van Walbeek 2010).

Percentage of quitters who avoid premature deaths. Smoking duration is far more important than the number of cigarettes smoked per day. With the assumption that low-price cigarettes are equally dangerous as high-price cigarettes, tobacco-related mortality is determined solely by smoking prevalence and not by smoking intensity (TETSiM 2010). It is a widely estimated statistic that regular smokers have a 50 per cent probability of dying from a smoking-related disease (Chaloupka et al. 2019; van Walbeek 2010). However, various studies show that the proportion of smoking-related mortality that could be averted if a smoker quits smoking is substantially smaller than 0.50 (TETSiM 2010). Based on Barber et al. (2008), we estimate the proportion of quitters who avoid premature deaths at 0.35 .

Total cigarette consumption. Estimates of cigarette consumption are key in determining the smoking intensity of the smoking population within the country. GlobalData (2019) 
estimates that legitimate sales in 2017 were 1.3 billion pieces, down 20.2 per cent on 1990 levels. In assuming total sales as a proxy, then total cigarette consumption for 2017 in Ghana is estimated to be equivalent to 65 million packs.

Market share of brand category and CIF value for each brand category. Based on van Walbeek (2014) and data from the Ministry of Finance on import quantities, the relative share of premium cigarettes was approximated at 15 per cent, medium quality cigarettes at 60 per cent, and economy quality cigarettes at 25 per cent. In addition, the CIF amount, expressed as a percentage of retail price, was approximated at 22 per cent for premium quality cigarettes, 22 per cent for medium quality cigarettes and 17 per cent for economy quality cigarettes (van Walbeek 2014).

\subsection{Scenario simulation (proposed policy interventions)}

In this study, we propose four policy interventions based on the current tax structure and level in Ghana (2020 base year) to determine expected outcomes using the TETSiM model, simulated over the next two years (2021 and 2022). First, the study proposes a mixed tax system for Ghana that is mainly supported by the current ECOWAS directive (ECOWAS Protocol 2017). In this, we simulate tax policies by keeping the existing ad valorem rate $(175 \%)$, incorporating a general specific excise tax of GH\&2 per pack at the outset in line with the ECOWAS directive, and analyse the change in outcome over two time periods 2021 and 2022.

Additionally, various country-level observations show that taxes need to be increased regularly over time to offset inflation and income growth to counter increasing product affordability (Chaloupka et al. 2019; Contreary et al. 2015; Goodchild et al. 2016).

Specifically, countries with maximum impact of a mixed tax system rely heavily on the specific component (WHO 2010). Verguet et al. (2015) show that a 50 per cent increase in tobacco price through excise tax would lead to 231 million years of life gained over 50 years (out of which one-third would be gained in the lowest income quintile), and a gain of US\$703 billion of additional tax revenue from excise tax. As a result, we simulate two other policy interventions - increasing the specific excise introduced in this study by 50 per cent while maintaining the current government ad valorem rate, to assess the change in potential health and revenue outcomes. This implies a simulation of 175 per cent ad valorem with $\mathrm{GH} \mathbb{3}$ specific excise, and 175 per cent ad valorem with GH\$4 specific excise.

The final simulation assesses the impact of imposing a purely specific excise tax on fiscal and public health indicators. Given Ghana's average retail price of the most sold 20-pack

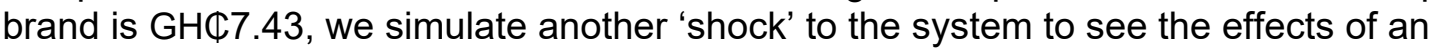
imposing a purely uniform specific excise tax of $\mathrm{GH}$ \5 as a tobacco price control mechanism, in keeping with the WHO minimum benchmark that stipulates 70 per cent retail price as excise tax. In all scenarios, each policy intervention will be assessed for 2021 and 2022, with 2020 as the base year. The possible scenarios are listed in Table 4. 
Table 4 Possible policy interventions

\begin{tabular}{|c|c|c|}
\hline Scenario & Possible policy intervention & Justification \\
\hline Scenario 1 & $\begin{array}{l}\text { Maintain } 175 \% \text { ad valorem and add a } \\
\text { specific tax of } \mathrm{GHC} 2.00(\mathrm{US} \$ 0.40) \text { per } \\
\text { pack }\end{array}$ & $\begin{array}{l}\text { This policy intervention simulates complete change from ad } \\
\text { valorem to mixed excise system in line with the minimum } \\
\text { threshold of the ECOWAS directive - at least } 50 \% \text { ad } \\
\text { valorem and specific excise equivalent to US } \$ 0.02 \text { per stick } \\
\text { (US } \$ 0.40 \text { per pack) }\end{array}$ \\
\hline Scenario 2 & $\begin{array}{l}\text { Maintain } 175 \% \text { ad valorem and add a } \\
\text { specific tax of GHC3.00 (US\$0.60) per } \\
\text { pack }\end{array}$ & $\begin{array}{l}\text { This policy intervention simulates a complete change from ad } \\
\text { valorem to mixed excise system with a } 50 \% \text { increase to the } \\
\text { minimum specific excise recommended by ECOWAS which } \\
\text { translates from US } \$ 0.40 \text { to US } \$ 0.60 \text { per pack. Mixed system } \\
\text { with maximum impact relies heavily on regular increase in } \\
\text { specific excise to adjust for inflation and economic growth }\end{array}$ \\
\hline Scenario 3 & $\begin{array}{l}\text { Maintain } 175 \% \text { ad valorem and add a } \\
\text { specific tax of GHC4.00 (US\$0.80) per } \\
\text { pack }\end{array}$ & $\begin{array}{l}\text { This policy intervention simulates a complete change from ad } \\
\text { valorem to mixed excise system with a } 100 \% \text { increase to the } \\
\text { minimum specific excise recommended by ECOWAS, which } \\
\text { translates from US } \$ 0.40 \text { to US } \$ 0.80 \text { per pack. Mixed system } \\
\text { with maximum impact relies heavily on regular increase in } \\
\text { specific excise to adjust for inflation and economic growth }\end{array}$ \\
\hline Scenario 4 & $\begin{array}{l}\text { Impose only specific tax of } \mathrm{GH} \mathbb{C 5 . 0 0} \\
\text { (US\$1.00) per pack }\end{array}$ & $\begin{array}{l}\text { This policy intervention simulates complete change from ad } \\
\text { valorem to specific excise tax system in line with the } \\
\text { minimum threshold of the WHO directive - at least } 70 \% \\
\text { excise tax of the retail price of the most sold brand. This is } \\
\text { equivalent to GHC5.00 (US } \$ 1.00) \text { per pack in Ghana }\end{array}$ \\
\hline $\begin{array}{l}\text { Baseline, } \\
2020\end{array}$ & Purely ad valorem of $175 \%$ & $\begin{array}{l}\text { This represents the current tax policy intervention to all } \\
\text { tobacco products (cigarettes, cigars and cigarillos) in Ghana. } \\
\text { It is levied on the CIF/import value of all tobacco imports. }\end{array}$ \\
\hline
\end{tabular}

\section{Results}

\subsection{Cigarette brands and prices}

In order to ascertain the retail price levels of tobacco, a survey was undertaken to determine current prices and quantities demanded of various bands of tobacco products in Ghana, especially cigarettes. The survey provides an insight into the price, brands, and vendor details of cigarettes sold in Ghana (see Table 5). Other study results are provided in Appendix 2-Appendix 7).

Table 5 Overview of cigarette price data in Ghana

\begin{tabular}{l|lllll}
\hline \multirow{2}{*}{ Category } & Ashanti & Central & Greater Accra & Northern & Total \\
\cline { 2 - 6 } & \multicolumn{5}{c}{} \\
\hline \hline $\begin{array}{l}\text { Average price per cigarette } \\
\text { stick (GHC) }\end{array}$ & 0.39 & 0.49 & 0.42 & 0.33 & 0.37 \\
N (Std. dev.) & $703(0.14)$ & $54(0.96)$ & $639(0.13)$ & $891(0.10)$ & $2287(0.37)$ \\
$\begin{array}{l}\text { Average price per pack of } \mathbf{2 0} \\
\text { cigarettes (GHC) }\end{array}$ & & & & & \\
N (Std. dev.) & 8.00 & 9.85 & 8.15 & 6.37 & 7.43 \\
& $636(2.86)$ & $54(1.93)$ & $632(2.47)$ & $891(2.06)$ & $2213(2.60)$
\end{tabular}

Source: Tobacco Control Survey in Ghana, 2020

\subsection{Simulation results}

Rodríguez-lglesias et al. (2017) argue that tax increase simulations support international evidence on the effectiveness of increasing taxes as a tobacco control measure. Using the TETSiM model, the results show the effect of four possible policy interventions in Ghana's tobacco tax structure and their impact on selected fiscal and public health outcomes. The 
base scenario is premised on relevant data from a variety of sources that best describes the recent cigarette industry in Ghana. The base scenario is presented in column 1 , with columns 2 and 3 showing the simulation effects of a mixed tax structure. Column 4 shows the result of imposing only a specific excise tax on the average price of cigarettes in Ghana (Table 6).

Table 6 Simulation results of imposing a uniform mixed tax and uniform specific tax system on cigarettes (fiscal effects)

\begin{tabular}{|c|c|c|c|c|c|}
\hline Fiscal effects & $\begin{array}{l}\text { Baseline } \\
\text { figures, } \\
2020\end{array}$ & $\begin{array}{l}\text { Scenario 1: Ad } \\
\text { valorem of } \\
175 \%+\text { specific } \\
\text { tax of GHC2 }\end{array}$ & $\begin{array}{l}\text { Scenario } 2 \text { : Ad } \\
\text { valorem of } 175 \% \\
+ \text { specific tax of } \\
\text { GHđ3 }\end{array}$ & $\begin{array}{l}\text { Scenario } 3: \text { Ad } \\
\text { valorem of } 175 \% \\
+ \text { specific tax of } \\
\text { GH®4 }\end{array}$ & 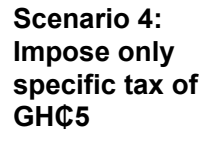 \\
\hline \multicolumn{2}{|r|}{ (1) } & $(2)$ & (3) & $(4)$ & $(5)$ \\
\hline & \multicolumn{5}{|c|}{$\begin{array}{l}\text { Percentage change } \\
\text { Actual change }\end{array}$} \\
\hline $\begin{array}{l}\text { Average retail price } \\
\text { (weighted) (GHC) }\end{array}$ & 6.79 & 64.1 & 96.1 & 128.1 & 152.4 \\
\hline $\begin{array}{l}\text { Average excise tax burden } \\
(\%)\end{array}$ & 6.68 & 27.2 & 33.9 & 39.1 & 41.6 \\
\hline $\begin{array}{l}\text { Total cigarette } \\
\text { consumption (million } \\
\text { packs) }\end{array}$ & 65 & -16.8 & -22.5 & -27.2 & -29.5 \\
\hline $\begin{array}{l}\text { Actual change in } \\
\text { consumption (million packs) }\end{array}$ & & -10.9 & -14.6 & -17.7 & -19.2 \\
\hline $\begin{array}{l}\text { Total tobacco industry } \\
\text { revenue (GHC million) }\end{array}$ & 343.63 & -16.2 & -21.8 & -26.4 & -28.7 \\
\hline $\begin{array}{l}\text { Tobacco levy } \\
\text { (ECOWAS/import duty) } \\
\text { Revenue (GHC million) }\end{array}$ & 3.07 & -16.3 & -21.9 & -26.5 & -28.8 \\
\hline $\begin{array}{l}\text { Excise tax revenue (GHC } \\
\text { million) }\end{array}$ & 28.97 & 357.0 & 499.5 & 626.9 & 691.1 \\
\hline $\begin{array}{l}\text { Actual change in excise } \\
\text { (GHC million) }\end{array}$ & & 103.4 & 144.7 & 181.6 & 200.2 \\
\hline VAT revenue (GHC million) & 65.74 & 12.6 & 18.4 & 24.0 & 26.9 \\
\hline $\begin{array}{l}\text { Total government revenue } \\
\text { (GHC million) }\end{array}$ & 97.78 & 113.8 & 159.7 & 201.0 & 221.9 \\
\hline $\begin{array}{l}\text { Actual change in total } \\
\text { revenue (GHष million) }\end{array}$ & & 111.2 & 156.1 & 196.6 & 217.0 \\
\hline $\begin{array}{l}\text { Total expenditure on } \\
\text { cigarettes (GHC million) }\end{array}$ & 441.42 & 12.6 & 18.4 & 24.0 & 26.9 \\
\hline
\end{tabular}

Source: Tobacco Control Survey in Ghana, 2020

\subsubsection{Fiscal effects}

Our first simulation analyses the effect of a mixed tax structure - the current 175 per cent ad valorem and a uniform specific of GHC2 per pack - and its impact on government revenue and public health. From Table 6 (column 2), should the government introduce a uniform specific tax of GHC2 per pack, equivalent to the ECOWAS directive of US $\$ 0.40$ per pack of 20 cigarettes, in addition to the current 175 per cent ad valorem, the retail price will increase significantly - by approximately 64 per cent, which would translate to an average retail price of about $\mathrm{GH} \mathbb{1 1} 1$ per pack of 20 cigarettes. Cigarette consumption is also expected to reduce by about 10.9 million packs, equivalent to 17 per cent. Excise tax revenue from tobacco 
taxation is also expected to increase by approximately 357 per cent to about $\mathrm{GHC} 132$ million, all things being equal. Consequently, the overall tobacco-related government tax revenue (sum of the excise, VAT, ECOWAS duty and other import levies) is expected to increase by 114 per cent to approximately GHC209 million. Estimates from GDHS and WHO show that government tax revenue from tobacco taxation increased by 73 per cent on average between 2014 and 2017 (GDHS 2014b; WHO 2019).

Various studies have shown that in many countries an increase in taxes, along with raised tobacco product prices, leads to the largest reduction in smoking, especially among lowestincome people; the tax burden as a result of the increase is relatively heavier on higherincome consumers (Gilmore et al. 2013; Wilkinson et al. 2019; Zheng and Huang 2015). Based on this, if the specific excise tax introduced in this study were to be increased with the current ad valorem rate of the CIF value, we would observe proportional changes in the outcome variables. It could be observed from column 3 that a mixed tax structure of 175 per cent ad valorem with a specific component of $\mathrm{GH} \mathbb{3}$ per cigarette pack would increase the average retail price by 96 per cent, decrease cigarette consumption by 22.5 per cent, and increase excise tax revenue by 499.5 per cent, and overall tobacco-related tax revenue by 159.7 per cent. With this, it is observed that the excise tax revenue would increase to approximately $\mathrm{GH} \mathbb{1 7 3 . 7}$ million, resulting in an increase in total government revenue to approximately $\mathrm{GH} \mathbb{2} 253.9$ million.

From column 4, we observe that, should the government maintain the current ad valorem rate of 175 per cent of CIF value and concurrently impose a uniform specific tax of GHC4 on each pack of cigarette (twice the ECOWAS specific benchmark), it will have proportionally significant consequences compared to the current purely ad valorem tax system. Given the assumptions of the model, the retail price is expected to increase by 128 per cent to an average price of about $\mathrm{GH} \mathbb{C} 15.50$ per pack, with a resultant decrease in cigarette consumption by 27.2 per cent - representing 373.1 million fewer cigarettes compared to the baseline (2020). The excise tax revenue will increase by 626.9 per cent and overall tobaccorelated government tax revenue by 201 per cent. This implies that the increase in excise tax revenue would be approximately $\mathrm{GH} 181.6$ million, pushing the excise revenue generated to about GHФ210.6 million. Consequently, with an increase of GHđ196.6 million, total government revenue from tobacco taxation is expected to increase to approximately GH\$294.4 million. Despite these significant changes, we are mindful that tobacco consumption in Ghana is not on a large scale, and thus the revenue potential from this scenario could be overstated. The study by van Walbeek (2014) shows that, despite increased tobacco tax revenue, this increase is modest - between 0.028 per cent to 0.073 per cent of Ghana's GDP.

Further, this paper decided to predict the resulting effect if the government should implement a purely uniform specific tax system (column 5) with the same set of assumptions that was used to derive the results in the base scenario (column 1). Although specific excise tax is easier to implement than ad valorem, it can be eroded by inflationary pressure (WHO 2010). The simulation results in column 5 show that the average retail price would be expected to increase by about 152 per cent, with a resultant decrease in cigarette consumption by 29.5 per cent. The imposition of the uniform specific tax is also expected to generate excise tax revenue from $\mathrm{GH} \mathbb{2} 28.97$ million to about $\mathrm{GH} \mathbb{2} 229.2$ million, resulting in total government revenue from tobacco taxation increasing by 221.9 per cent - raising it to approximately GHđ315 million. 


\subsubsection{Demographic and public health effects}

A decrease in total cigarette consumption can come about in two ways: fewer smokers (a decrease in smoking prevalence), or less cigarettes smoked by smokers (a decrease in smoking intensity) (van Walbeek 2010). Given the current prevalence rate in Ghana and the estimated size of the population, the model further calculates and predicts the absolute number of people who are expected to quit smoking, and the number that will be saved from premature tobacco-related deaths for two time periods (2021 and 2022) with the base year of 2020 (Table 7). According to Flanders et al. (2003) and van Walbeek (2010), smokingrelated mortality is more closely associated with smoking prevalence than smoking intensity, hence a larger decrease in smoking prevalence is a better public health outcome.

Table 7 Simulation results of demographic/public health effects (with 2-year projection)

\begin{tabular}{|c|c|c|c|c|c|c|c|c|c|}
\hline \multirow{3}{*}{$\begin{array}{l}\text { Demographic/pub } \\
\text { lic health effects } \\
\text { (with 2-year } \\
\text { projection) }\end{array}$} & \multirow[t]{3}{*}{$\begin{array}{l}\text { Baseline } \\
\text { figures, } \\
2020\end{array}$} & \multirow{2}{*}{\multicolumn{2}{|c|}{$\begin{array}{l}\text { Scenario 1: Ad } \\
\text { valorem of } 175 \%+ \\
\text { specific tax of } \\
\text { GHC2 } \\
\text { (1) }\end{array}$}} & \multirow{2}{*}{\multicolumn{2}{|c|}{$\begin{array}{l}\text { Scenario 2: Ad } \\
\text { valorem of } 175 \%+ \\
\text { specific tax of } \mathrm{GH} \nsubseteq 3 \\
\text { (2) }\end{array}$}} & \multirow{2}{*}{\multicolumn{2}{|c|}{$\begin{array}{l}\text { Scenario } 3: \text { Ad } \\
\text { valorem of } 175 \%+ \\
\text { specific tax of } \\
\text { GHథ4 } \\
\text { (3) }\end{array}$}} & \multirow{2}{*}{\multicolumn{2}{|c|}{$\begin{array}{l}\text { Scenario 4: } \\
\text { Impose only } \\
\text { specific tax of } \\
\text { GHథ5 } \\
(4)\end{array}$}} \\
\hline & & & & & & & & & \\
\hline & & 2021 & 2022 & 2021 & 2022 & 2021 & 2022 & 2021 & 2022 \\
\hline $\begin{array}{l}\text { Number of } \\
\text { cigarettes smoked } \\
\text { (aggregate, billion) }\end{array}$ & 1.30 & 1.07 & 0.88 & 0.99 & 0.75 & 0.93 & 0.66 & 0.90 & 0.62 \\
\hline $\begin{array}{l}\text { Number of } \\
\text { cigarettes smoked } \\
\text { per smoker per } \\
\text { year (smoking } \\
\text { intensity), } \\
\text { measured in } \\
\text { cigarettes per year }\end{array}$ & 1754.4 & 1573.0 & 1410.4 & 1505.3 & 1291.6 & 1447.8 & 1194.8 & 1419.2 & 1148.0 \\
\hline $\begin{array}{l}\text { Number of } \\
\text { cigarettes smoked } \\
\text { per smoker per day }\end{array}$ & 4.8 & 4.3 & 3.9 & 4.1 & 3.5 & 4.0 & 3.3 & 3.9 & 3.1 \\
\hline $\begin{array}{l}\text { Smoking } \\
\text { prevalence (of the } \\
\text { adult population) } \\
(\%)\end{array}$ & 3.8 & 3.5 & 3.2 & 3.4 & 3.0 & 3.3 & 2.8 & 3.2 & 2.8 \\
\hline $\begin{array}{l}\text { Number of } \\
\text { smokers (million) }\end{array}$ & 0.74 & 0.68 & 0.62 & 0.66 & 0.58 & 0.64 & 0.55 & 0.63 & 0.54 \\
\hline $\begin{array}{l}\text { Number of } \\
\text { premature deaths } \\
\text { avoided (thousand) }\end{array}$ & & 2.18 & 1.99 & 2.92 & 2.59 & 3.53 & 3.05 & 3.82 & 3.26 \\
\hline
\end{tabular}

Source: Tobacco Control Survey in Ghana, 2020

For scenario 1 (Table 7 column 1), cigarette consumption would reduce by 16.8 per cent as a result of reducing the number of cigarettes smoked by approximately 17.9 per cent, from 1.3 billion sticks to 1.07 billion sticks in 2021, and to 0.88 billion sticks in 2022 . Consequently, the smoking intensity (the number of cigarettes smoked per smoker per year) would also reduce by approximately 0.1 per cent to 1,573 cigarettes per year in 2021 , and 1,410 cigarettes per year in 2022. Additionally, given an adult population of approximately 19.5 million, it is expected that the prevalence rate would decrease by 0.5 percentage points, to 3.5 per cent in 2021 and 3.19 per cent in 2022. The number of smokers is expected to decrease from about 741,000 to 678,804 in 2021 and to 621,829 in 2022 . It is expected that 2,177 and 1,994 premature deaths would be avoided in 2021 and 2022 respectively with the tax rate imposed,.

A corresponding proportional change is seen in column 2 for Scenario 2. The number of cigarettes smoked reduces by 24 per cent, equivalent to about 310 million sticks in 2021 and 
546 million sticks in 2022 . The smoking intensity reduces to 1,505 and 1,291 cigarettes per year for 2021 and 2022 respectively, while smoking prevalence reduces to 3.4 per cent and 3 per cent in 2021 and 2022 respectively. The number of premature deaths avoided is estimated to be around 2,921 in 2021 and 2,592 in 2022.

For the third scenario, the resulting predicted estimates show that all public health indicator effects improved significantly (because of the specific component) compared to the current ad valorem excise tax (scenario 3). The predicted estimates for 2021 and 2022 reveal that cigarette consumption reduces by 28.7 per cent and 49.2 per cent; smoking intensity declines by 0.2 per cent and 0.3 per cent; smoking prevalence reduces to 3.3 per cent and 2.8 per cent, with the number of premature deaths expected to be avoided around 3,526 and 3,047 human lives, respectively, for both time periods.

In the final scenario, the results showed a highly predicted intuitive output. With just marginal differences, the predicted results show a significant improvement in public health indicators, similar to the mixed system of 175 per cent ad valorem with $\mathrm{GH} \mathbb{C} 4$ specific tax. This further strengthens the need for regular increases in tobacco taxes to improve public health outcomes.

\subsubsection{Discussion}

This study argues that increased taxes are critical for the maximum fiscal and public health impact. Jha and Chaloupka (2000) strongly argue that tax increases are the single most effective intervention to reduce demand for tobacco. Increased tobacco taxation has been shown to be a pro-poor instrument that brings substantial health and financial benefits (Verguet et al. 2015). In Nigeria, although the government introduced a specific tax of 20 (\$0.07) in 2018 in addition to the current ad valorem rate of 20 per cent, with a rise to $\$ 40$ (\$0.13) and $\$ 58$ (\$0.13) in 2019 and 2020 , the proportion of excise tax (16.4\%) to the retail price in 2018 was still less than the WHO benchmark (70\%) (Akanonu et al. 2018). Simulated results of the proposed tax policies showed marginal impact on public health, and relatively higher impact on government revenue (Akanonu et al. 2018).

The impact of a mixed tax system in generating maximum government revenue, as well as improving public health, is based on regular increase in the specific component of the excise tax (Chaloupka et al. 2019; WHO 2010). Chaloupka et al. (2019) and Wilkinson et al. (2019) show that large tax increases are effective in reducing smoking prevalence, especially among those of lower socio-economic status groups. This is very critical in the case of Ghana - a large proportion of the smoking population are in the northern regions of the country, who are of low socio-economic status compared to those in the South. Estimates from the Ghana Demographic and Health Survey show that the highest prevalence rate, especially amongst male adults, are in the Northern (9.6\%), Upper East (10.3\%) and Upper West $(8.6 \%)$ regions (GDHS 2014a).

Looking at both the fiscal and public health effects, imposing a relatively high uniform specific tax coupled with the current ad valorem would require strong political will because of opposition from the tobacco industry. The tobacco industry employs strategies to negate the full effects of an increase in tobacco taxes. According to Ross et al. (2017), these legal strategies include the following: stockpiling, changing product attributes or product processes, lowering prices, over-shifting and under-shifting prices, timing of price increases and engaging in price discrimination and/or offering promotions. Additionally, the tobacco industry may argue that tax increases would increase illicit trade. However, according to van Walbeek (2014), these statements are made as articles of faith, with little, if any, empirical evidence to back them up. In this regard, and given potential illicit trade, WHO recommends 
that a specific mixed tax system would require strong tax administration with technical capacity - the administrative burden can be high, requiring assessing and collecting both ad valorem and specific excises. Kenya and Brazil are using GPS-based tracking and tracing devices to curtail illicit trade (van Walbeek 2014), and these technologies are becoming increasingly affordable. Ghana's digital tax stamp system is a good example that needs to be sustained to ensure maximum impact.

Although there are a national coordinating mechanism and tobacco control policies, a robust surveillance system needs to be set up to continuously evaluate policy interventions to control tobacco, along with systems that will aid the administrative capacity of the tax and customs department to counter the illicit tobacco market. Currently in Ghana, policy guidelines on how to engage with the tobacco industry in protecting public health policy from influence by vested interests is limited. There is also a low level of awareness of the extent of tobacco industry interference (FCTC article 5.3) in controlling market prices (Singh et al. 2020). Tobacco product importers regularly lobby to halt further increases in tobacco taxation in Ghana (Wellington 2017). Therefore, mechanisms to strengthen tax administration and protect public health policies from tobacco industry interference should also be prioritised.

\subsubsection{Limitations}

The paper uses the weighted average price of all cigarette brand segments across geographical location for its analysis in the model. However, the study acknowledges variation in cigarette brand prices across the regional locations from which data was collected as depicted in Table 5 above (with standard deviations in brackets) and Appendix 3, Appendix 4 and Appendix 6 (showing prices). Generally, average cigarette prices in the southern belt (Greater Accra and Central regions) are relatively higher, followed by the middle belt (Ashanti region), with the northern belt (Northern region) recording relatively lower cigarette prices. Further research could be undertaken to critically assess the determinants of the regional variation in cigarette prices in Ghana. Given these differences results should be interpreted with care, as modelling estimates for each geographical location for which data was collected may vary. It is possible that, on average, the estimated results from the model in this paper may be overestimated for those in the northern belt, compared to those in the southern belt.

In practical terms, the model does not consider other complicated taxation structures - for example, taxes subject to weight, length or price thresholds - but rather the average market price segments, since cigarette prices in Ghana are largely determined by their brands. Additionally, the model does not include non-tobacco control interventions, such as income of consumers and the inflation and economic growth rate, which are key to cigarette consumption. At the policy level, since it is relatively difficult to adjust consumers' income downwards to reduce consumption, this paper suggests that tax on cigarette prices should be adjusted in line with changes in the rate of inflation and economic growth. This is to ensure an effective real impact of price increases in reducing cigarette consumption and improving public health, especially in the long term.

The survey was limited to collecting general market prices of cigarettes and other tobacco products, with less focus on contraband or illicit products. There is limited quantitative data on volume and market size of the illicit market for tobacco in Ghana. Data on the illicit market could be useful in predicting losses in government tax revenue. In view of this, caution should be taken in interpretation of the results - the model may be slightly overestimated, taking into consideration the likelihood of the presence of tax revenue from contraband that may not accrue to the government. Nonetheless, in addition to controlling the tobacco market in Ghana, given the implementation of the Public Health Act, 2012 (Act 851) and tobacco 
control regulations, 2016 (L.I. 2247) by both the Food and Drugs Authority (FDA) and the Ghana Revenue Authority (GRA) in the market, it is expected that the influence of illicit brands may be further curtailed. Anecdotal evidence from the cigarette price survey suggests that strict implementation of the pictorial health warning symbols, in addition to existing tariffs and tax stamps on all cigarette packs in Ghana, is expected to further discourage mass import of illicit brands due to recent increases in the random security checks in the market by officials of these institutions. This presents an opportunity for further research. Hence, the model presents reasonable estimates to aid government policy decisions.

\section{Conclusion and recommendation}

The paper makes rational quantitative conclusions based on field survey data and relevant literature that inform the parameter values for the base scenario. In effect, for all price elasticity values for each market, an increase in excise tax decreases cigarette consumption, smoking prevalence, smoking intensity and smoking-related mortality. The structure of the excise plays a critical part in this regard. If the excise tax is levied as a specific tax, it significantly improves the fiscal and public health effects - but it is eroded by inflation. Although the country imposes the highest ad valorem tax rate of 175 per cent in SSA, it is burdened with consequential challenges such as susceptibility to undervaluation of tobacco products, as well as encouraging a trading-down effect in favour of cheaper cigarettes, which reduces the health benefits.

Due to the current tax policy approach being implemented by the government on all excisable products, coupled with the recent ECOWAS directive on tobacco control and the recommendations of the FCTC protocol, a mixed tax system (current ad valorem of 175 per cent with uniform specific of GHФ4 per pack) is recommended to ensure the full benefits of the fiscal and public health impact of tobacco taxation in Ghana. However, effective implementation of the specific mixed tax system requires strong tax administration with technical capacity. It is also recommended that the Ministry of Finance regularly adjusts the nominal excise tax by the rate of inflation and economic growth over time, to ensure the product does not become more affordable. Such an annual inflationary increase should be a standard policy. Strong political will is essential, as there are several strategies taken by the tobacco industry to negate the positive effects of tobacco tax increases.

A uniform (as opposed to tiered) tax structure is recommended to prevent tobacco companies from lowering prices to change to a lower tax rate tier. Currently, there is a lack of comprehensive local data and skilled research on tobacco in Ghana. Additionally, to inform policy on effective tax implementation there is an urgent need for more local and comprehensive research on tobacco prevalence and use, as well as its determinants especially across age and geographical locations - to determine the trend in price variations. Finally, although Ghana has a national coordinating mechanism and tobacco control policies, there is a need for regular evaluation of tobacco policy interventions, in addition to tobacco industry mapping and monitoring. A robust administrative capacity in the tax and customs departments is also necessary, as there are increasing numbers of contraband brands of cigarette products. 


\section{Appendices}

\section{Appendix 1 Summary of fieldwork}

\section{Training of enumerators}

Qualified and experienced interviewers were trained from Tuesday, 4 February to Thursday, 6 February 2020. Training took place at the conference facility at ISSER, University of Ghana. Training covered the use of the survey instrument, how to engage with vendors to ensure buy-in and overall comportment in the field. The last day was dedicated to pre-testing the instrument in various parts of Accra. A session was dedicated to feedback from the pretesting to allow corrections to be made, and to share strategies to ensure accurate data collection.

\section{Sampling}

We sampled from the Northern Region, which has the highest intensity of users, Ashanti region, which is in the middle belt and has the second largest city, and Greater Accra region, where the capital city is located. For each of the three regions, a number of enumeration areas were randomly selected in urban and rural areas. The study covered all three categories of shops where tobacco products were sold (large shops/supermarkets, small shops and vendors).

\section{Study team}

The study team comprised nine fieldworkers of which three were supervisors. There were eight male and one female interviewers. Fieldwork started on Monday, 10 February 2020 with three teams - Northern, Ashanti and Greater Accra Regions. The fieldwork was carried out for a period of fifteen days, which included travel days. 
Appendix 2 Tobacco survey enumeration areas

\begin{tabular}{|c|c|c|}
\hline Region & Town/enumeration area & $\begin{array}{l}\text { Locality } \\
\text { Type }\end{array}$ \\
\hline \multirow{9}{*}{$\begin{array}{l}\text { Greater } \\
\text { Accra }\end{array}$} & Tema Community 1 (Centre, Market area, Site $18,19,20)$ & Urban \\
\hline & $\begin{array}{l}\text { Ashaiman (18, Night Market, Kufuor Station, Frafra Market, Roman, Western Ventures, I Shall } \\
\text { Return) }\end{array}$ & Urban \\
\hline & Baatsona (Baatsona Highway, Baatsona/Adegon Railway, Crysberry, 16 Road) & Urban \\
\hline & Spintex (Nyiraba Kodjo area) & Urban \\
\hline & Nungua (Katamanto to the main market) & Urban \\
\hline & Lashibi (Shalom Spot area, Estate Junction) & Urban \\
\hline & Sakumono (Community 14, Beach road (Sakomono village)) & Urban \\
\hline & Domeabra & Rural \\
\hline & Danchira & Rural \\
\hline \multirow[t]{5}{*}{ Central } & Kasoa Zone 6 & Urban \\
\hline & Kasoa (High Tension, Ghana Flag) & Urban \\
\hline & Obom Junction & Urban \\
\hline & Kasoa, Old Station near school Junction & Urban \\
\hline & Kasoa-Winneba Highway & Urban \\
\hline \multirow[t]{13}{*}{ Ashanti } & Kejetia & Urban \\
\hline & Kronum & Urban \\
\hline & Oforikrom & Urban \\
\hline & Bantama & Urban \\
\hline & Ayigya & Urban \\
\hline & Denase & Rural \\
\hline & Danase & Rural \\
\hline & Kodee & Rural \\
\hline & Buoho & Rural \\
\hline & Afrancho & Rural \\
\hline & Adubinsu Besease & Rural \\
\hline & Edwenase & Rural \\
\hline & Maase & Rural \\
\hline \multirow[t]{17}{*}{ Northern } & Lamashegu & Urban \\
\hline & Tishigu & Urban \\
\hline & Sakasaka & Urban \\
\hline & Ababoo Market Area & Urban \\
\hline & Areas around the Tamale Metro Mass Area & Urban \\
\hline & Bus Stop (Main Lorry Station) & Urban \\
\hline & Taxi rank, not far from the Bus Stop & Urban \\
\hline & Nyohini (Nyohni) & Urban \\
\hline & Gbashe & Rural \\
\hline & Dohini & Rural \\
\hline & Manguli & Rural \\
\hline & Banvim & Rural \\
\hline & Jonshegu & Rural \\
\hline & Banvim Dakkpemyili & Rural \\
\hline & Janton & Rural \\
\hline & Daluayili & Rural \\
\hline & Gumu (along the Kumbugu-Tamale road) & Rural \\
\hline
\end{tabular}


Appendix 3 Average price, by outlet type across region

\begin{tabular}{|c|c|c|c|c|c|}
\hline Outlet type & Ashanti & Central & Greater Accra & Northern & Total \\
\hline & GHC & GHC & GHC & GHC & GHC \\
\hline \multicolumn{6}{|l|}{ Large shop } \\
\hline Average per cigarette price & 0.32 & 0.35 & 0.33 & 0.34 & 0.33 \\
\hline Average 20-pack price & 6.48 & 7.00 & 6.50 & 6.71 & 6.53 \\
\hline Total observations & 48 & 6 & 47 & 7 & 108 \\
\hline \multicolumn{6}{|l|}{ Small shop } \\
\hline Average per cigarette price & 0.40 & 0.51 & 0.43 & 0.33 & 0.39 \\
\hline Average 20-pack price & 8.27 & 10.14 & 8.41 & 6.37 & 7.72 \\
\hline Total observations & 512 & 43 & 514 & 531 & 1600 \\
\hline \multicolumn{6}{|l|}{ Vendor } \\
\hline Average per cigarette price & 0.37 & 0.09 & 0.38 & 0.33 & 0.35 \\
\hline Average 20-pack price & 7.56 & 10.80 & 7.36 & 6.36 & 6.81 \\
\hline Total observations & 128 & 5 & 74 & 353 & 560 \\
\hline
\end{tabular}

Source: Tobacco Control Survey in Ghana, 2020

Appendix 4 Average price per cigarette, by pack size (and region)

\begin{tabular}{llllll}
\hline \multirow{2}{*}{ Pack size } & Ashanti & Central & Greater Accra & Northern & Total \\
\cline { 2 - 6 } & GH屯 & GHC & GHC & GHC & GHC \\
10-pack & 0.26 & - & 0.26 & - & 0.26 \\
20-pack & 0.40 & 0.49 & 0.42 & 0.33 & 0.38 \\
\hline
\end{tabular}

Source: Tobacco Control Survey in Ghana, 2020

Appendix 5 Brand popularity: top 5 brands, by region

\begin{tabular}{|c|c|c|c|c|c|c|c|}
\hline Ashanti & & Central & & Greater Accra & & Northern & \\
\hline Brand name & Freq & Brand name & Freq & Brand name & Freq & Brand name & Freq \\
\hline London & 288 & London & 17 & Rothmans & 189 & $\begin{array}{l}\text { Business } \\
\text { Royals }\end{array}$ & 244 \\
\hline Rothmans & 174 & Rothmans & 16 & London & 188 & London & 183 \\
\hline Gold Seal & 69 & $\begin{array}{l}\text { Pall Mall } \\
\text { Benson \& }\end{array}$ & 14 & $\begin{array}{l}\text { Pall Mall } \\
\text { Business }\end{array}$ & 182 & $\begin{array}{l}\text { Rothmans } \\
\text { State }\end{array}$ & 158 \\
\hline Pall Mall & 67 & $\begin{array}{l}\text { Hedges } \\
\text { Business }\end{array}$ & 4 & Royals & 28 & Express & 119 \\
\hline State Express & 53 & Royals & 2 & State Express & 19 & Pall Mall & 85 \\
\hline \multirow{2}{*}{$\begin{array}{l}\text { Total observations } \\
\text { Contribution to total } \\
\text { obs. (\%) }\end{array}$} & 703 & & 54 & & 647 & & 891 \\
\hline & $93 \%$ & & $98 \%$ & & $94 \%$ & & $89 \%$ \\
\hline
\end{tabular}

Source: Tobacco Control Survey in Ghana, 2020 
Appendix 6 Average price of cigarette brands (by region)

\begin{tabular}{|c|c|c|c|c|c|c|c|c|c|c|}
\hline \multirow[b]{2}{*}{ Brand Name } & \multicolumn{2}{|l|}{ All } & \multicolumn{2}{|c|}{ Ashanti } & \multicolumn{2}{|c|}{ Central } & \multicolumn{2}{|c|}{ Greater Accra } & \multicolumn{2}{|c|}{ Northern } \\
\hline & Mean & Freq & Mean & Freq & Mean & Freq & Mean & Freq & Mean & Freq \\
\hline & $\underline{\mathrm{GHC}}$ & & $\underline{\mathrm{GHC}}$ & & $\underline{\mathrm{GHC}}$ & & $\underline{\mathbf{G H C}}$ & & $\underline{\mathbf{G H C}}$ & \\
\hline Alishan & 0.5 & 1 & - & - & - & - & 0.5 & 1 & - & - \\
\hline $\begin{array}{l}\text { Benson \& } \\
\text { Hedges }\end{array}$ & 0.72 & 13 & - & - & 0.7 & 4 & 0.73 & 9 & - & - \\
\hline Business & 0.4 & 1 & - & - & 0.5 & 2 & - & - & 0.4 & 1 \\
\hline Business Club & 0.2 & 1 & - & - & - & - & - & - & 0.2 & 1 \\
\hline $\begin{array}{l}\text { Business } \\
\text { Royals }\end{array}$ & 0.29 & 290 & 0.4 & 16 & - & - & 0.51 & 28 & 0.25 & 244 \\
\hline Captain Black & 1 & 1 & 1 & 1 & - & - & - & - & - & - \\
\hline City Express & 0.25 & 1 & & & - & - & 0.25 & 1 & - & - \\
\hline Fisher & 0.23 & 16 & 0.24 & 14 & - & - & 0.17 & 2 & - & - \\
\hline Gold Seal & 0.26 & 76 & 0.26 & 69 & - & - & 0.25 & 7 & - & - \\
\hline Golden Deer & 0.5 & 2 & - & - & - & - & 0.5 & 2 & - & - \\
\hline London & 0.37 & 676 & 0.38 & 288 & 0.47 & 17 & 0.4 & 188 & 0.3 & 183 \\
\hline Marlboro & 0.7 & 3 & 0.9 & 1 & - & - & 0.6 & 2 & - & - \\
\hline Mile & 0.23 & 3 & - & - & - & - & - & - & 0.23 & 3 \\
\hline Oris & 0.28 & 108 & 0.24 & 15 & - & - & 0.35 & 12 & 0.28 & 81 \\
\hline Pall Mall & 0.31 & 347 & 0.24 & 67 & 0.42 & 14 & 0.34 & 181 & 0.28 & 85 \\
\hline Rothmans & 0.45 & 532 & 0.46 & 174 & 0.53 & 16 & 0.47 & 184 & 0.42 & 158 \\
\hline Sir & 0.26 & 17 & 0.24 & 5 & - & - & 0.5 & 1 & 0.24 & 11 \\
\hline State Express & 0.52 & 192 & 0.59 & 53 & 0.5 & 1 & 0.52 & 19 & 0.49 & 119 \\
\hline Timeless Time & 0.23 & 4 & - & - & - & - & - & - & 0.23 & 4 \\
\hline Tusker & 0.5 & 1 & - & - & - & - & 0.5 & 1 & - & - \\
\hline Yes & 0.35 & 2 & - & - & - & - & 0.5 & 1 & 0.2 & 1 \\
\hline Total & 0.37 & 2287 & 0.39 & 703 & 0.49 & 54 & 0.42 & 639 & 0.33 & 891 \\
\hline
\end{tabular}

Source: Tobacco Control Survey in Ghana, 2020 


\section{Appendix 7 Detail simulation results of imposing a mixed tax system and a uniform}

specific tax on cigarettes

\begin{tabular}{|c|c|c|c|c|c|c|c|c|c|c|c|c|c|c|c|c|}
\hline \multirow[b]{3}{*}{ Percentage change in: } & \multicolumn{4}{|c|}{$\begin{array}{l}\text { Scenario 1: Ad valorem of } 175 \%+ \\
\text { Specific tax of GHS2.00 }(\$ 0.40)\end{array}$} & \multicolumn{4}{|c|}{$\begin{array}{c}\text { Scenario 2: Ad valorem of } 175 \%+ \\
\text { Specific tax of GHS3.00 }(\$ 0.60)\end{array}$} & \multicolumn{4}{|c|}{$\begin{array}{l}\text { Scenario 3: Ad valorem of } 175 \%+ \\
\text { Specific tax of GHS4.00 }(\$ 0.80)\end{array}$} & \multicolumn{4}{|c|}{$\begin{array}{c}\text { Scenario 4: Impose only Specific tax } \\
\text { of GHS5.00 (\$1.00) }\end{array}$} \\
\hline & \multicolumn{4}{|c|}{ (1) } & \multicolumn{4}{|c|}{ (2) } & \multicolumn{4}{|c|}{ (3) } & \multicolumn{4}{|c|}{ (4) } \\
\hline & Premium & Medium & Economy & Total & Premium & Medium & Economy & Total & Premium & 1 Medium & Economy & Total & Premium & 1 Medium & Economy & Total \\
\hline Retail Price & 25.1 & 34.4 & 45.9 & 64.1 & 37.6 & 51.5 & 68.8 & 96.1 & 50.1 & 68.7 & 91.8 & 128.1 & 56.7 & 77.8 & 106.4 & 152.4 \\
\hline Total Cigarette Consumption & -14.6 & -14.1 & -24.5 & -16.8 & -20.6 & -19.0 & -32.1 & -22.5 & -25.8 & -23.0 & -38.1 & -27.2 & -28.4 & -24.8 & -41.4 & -29.5 \\
\hline Actual Change in Consumption (million packs) & -1.4 & -5.5 & -4.0 & -10.9 & -2.0 & -7.4 & -5.2 & -14.6 & -2.5 & -9.0 & -6.2 & -17.7 & -2.8 & -9.7 & -6.7 & -19.2 \\
\hline Total Industry Revenue & -14.6 & -14.1 & -24.5 & -16.2 & -20.6 & -19.0 & -32.1 & -21.8 & -25.8 & -23.0 & -38.1 & -26.4 & -28.4 & -24.8 & -41.4 & -28.7 \\
\hline Tobacco Levy & -14.6 & -14.1 & -24.5 & -16.3 & -20.6 & -19.0 & -32.1 & -21.9 & -25.8 & -23.0 & -38.1 & -26.5 & -28.4 & -24.8 & -41.4 & -28.8 \\
\hline Excise Tax & 347.0 & 349.2 & 389.2 & 357.0 & 483.7 & 495.1 & 525.5 & 499.5 & 602.1 & 628.9 & 639.8 & 626.9 & 657.4 & 695.9 & 702.3 & 691.1 \\
\hline Actual Change in Excise (million GHS) & 16.0 & 64.4 & 23.1 & 103.4 & 22.3 & 91.2 & 31.2 & 144.7 & 27.7 & 115.9 & 38.0 & 181.6 & 30.3 & 128.3 & 41.7 & 200.2 \\
\hline VAT & 6.8 & 15.4 & 10.2 & 12.6 & 9.3 & 22.7 & 14.6 & 18.4 & 11.4 & 29.9 & 18.7 & 24.0 & 12.2 & 33.7 & 20.9 & 26.9 \\
\hline Total Government Revenue & 90.0 & 116.8 & 127.7 & 113.8 & 125.3 & 166.2 & 173.0 & 159.7 & 155.8 & 211.8 & 211.3 & 201.0 & 170.0 & 234.9 & 232.2 & 221.9 \\
\hline Actual Change in Total Revenue (million GHS) & 16.9 & 70.2 & 24.2 & 111.2 & 23.5 & 99.9 & 32.8 & 156.1 & 29.2 & 127.3 & 40.0 & 196.6 & 31.8 & 141.2 & 44.0 & 217.0 \\
\hline Total Expenditure & 6.8 & 15.4 & 10.2 & 12.6 & 9.3 & 22.7 & 14.6 & 18.4 & 11.4 & 29.9 & 18.7 & 24.0 & 12.2 & 33.7 & 20.9 & 26.9 \\
\hline Demographic/Public Health Effects & & $\begin{array}{c}\text { Baseline, } \\
2020\end{array}$ & 2021 & 2022 & & $\begin{array}{c}\text { Baseline, } \\
2020\end{array}$ & 2021 & 2022 & & $\begin{array}{c}\text { Baseline, } \\
2020\end{array}$ & 2021 & 2022 & & $\begin{array}{c}\text { Baseline, } \\
2020\end{array}$ & 2021 & 2022 \\
\hline $\begin{array}{l}\text { Number of cigarettes smoked (aggregate, } \\
\text { billions) }\end{array}$ & & 1.30 & 1.07 & 0.9 & & 1.30 & 1.0 & 0.8 & & 1.30 & 0.9 & 0.7 & & 1.30 & 0.9 & 0.6 \\
\hline $\begin{array}{l}\text { Number of cigarettes smoked per smoker per } \\
\text { year (smoking intensity), measured in } \\
\text { cigarettes per year }\end{array}$ & & 1754.4 & 1573.0 & 1410.4 & & 1754.4 & 1505.3 & 1291.6 & & 1754.4 & 1447.8 & 1194.8 & & 1754.4 & 1419.2 & 1148.0 \\
\hline $\begin{array}{l}\text { Number of cigarettes smoked per smoker per } \\
\text { day }\end{array}$ & & 4.81 & 4.31 & 3.86 & & 4.81 & 4.12 & 3.54 & & 4.81 & 3.97 & 3.27 & & 4.81 & 3.89 & 3.15 \\
\hline $\begin{array}{l}\text { Smoking prevalence (of the adult population) } \\
(\%)\end{array}$ & & 3.80 & 3.48 & 3.19 & & 3.80 & 3.37 & 2.99 & & 3.80 & 3.28 & 2.84 & & 3.80 & 3.24 & 2.76 \\
\hline Number of smokers (millions) & & 0.74 & 0.68 & 0.62 & & 0.74 & 0.66 & 0.58 & & 0.74 & 0.64 & 0.55 & & 0.74 & 0.63 & 0.54 \\
\hline $\begin{array}{l}\text { Number of premature deaths avoided } \\
\text { (thousands) }\end{array}$ & & & 2.18 & 1.99 & & & 2.92 & 2.59 & & & 3.53 & 3.05 & & & 3.82 & 3.26 \\
\hline
\end{tabular}

Source: Tobacco Control Survey in Ghana, 2020 


\section{References}

Akanonu, P., Ishaku, J. and Onyekwena, C. (2019) The economics of Tobacco Control in Nigeria: Modelling the Fiscal and Health Effects of a Tobacco Excise Tax Change in Nigeria, ICTD Working Paper 99, Brighton: Institute of Development Studies, https://doi.org/10.18332/tid/84729

(2018) Examining the implications of the recent change in Tobacco Tax Policy in Nigeria, retrieved 20 March 2020 from CSEA AFRICA website: http://cseaafrica.org/examining-the-implications-of-the-recent-change-in-tobacco-taxpolicy-in-nigeria/

Azomahou, T., Balde, R., Diagne, A., Mane, P. and Kaba, I. (2019) 'Public finances and tobacco taxation with product variety: Theory and application to Senegal and Nigeria', PLOS ONE 14(2): 1-21

Barber, S., Adioetomo, S., Ahsan, A. and Setyonaluri, D. (2008) Tobacco economics in Indonesia. In International Union Against Tuberculosis and Lung Disease, retrieved from https://www.tobaccofreekids.org/assets/global/pdfs/en/Indonesia_tobacco_taxes_repor t_en.pdf

Chaloupka, F., Hu, T., Warner, K., Jacobs, R. and Yurekli, A. (2000) 'The taxation of tobacco products', in P. Jha and F. Chaloupka (eds), Tobacco Control in Developing Countries, (January), Oxford University Press

Powell, L. and Warner, K. (2019) 'The Use of Excise Taxes to Reduce Tobacco, Alcohol, and Sugary Beverage Consumption', Annual Review of Public Health 40: 187201

Yurekli, A. and Fong, G. (2012) 'Tobacco taxes as a tobacco control strategy', Tobacco Control 21(2): 172-180, https://doi.org/10.1136/tobaccocontrol-2011-050417

Contreary, K., Chattopadhyay, S., Hopkins, D., Chaloupka, F., Forster, J., Grimshaw, V., ... Fielding, J. (2015) 'Economic Impact of Tobacco Price Increases Through Taxation: A Community Guide Systematic Review', American Journal of Preventive Medicine, 49(5): 800-808, https://doi.org/10.1016/j.amepre.2015.04.026

CRES (2014) Project on Tobacco Taxation in West Africa. Ghana Profile Regarding Tobacco Taxation. Optimizing the Taxation of Tobacco to speed-up Tobacco control, retrieved from http://www.otaf.info/sites/default/files/documents/Notes de politiques du Ghana.pdf

ECOWAS Protocol (2017) 'Directive on the Harmonization of Excise Duties on Tobacco Products in ECOWAS Member States', Seventy Ninth Ordinary Session of the Council of Ministers, Abuja, 13 -14 December 2017, 1-7, retrieved from http://ecotipa.ecowas.int/wp-content/uploads/2018/05/3-DIRECTIVE-TOBACCO-2017DEC-FOLDER.pdf

Flanders, W., Lally, C., Zhu, B., Henley, S. and Thun, M. (2003) 'Lung cancer mortality in relation to age, duration of smoking, and daily cigarette consumption: Results from cancer prevention study II', Cancer Research, 63(19): 6556-6562 
GDHS (2014a) 2014 Ghana Demographic and Health Survey, Rockville, Maryland, USA

(2014b) 'Ghana Demographic and Health Survey. Overview of the Health System in Ghana', Ghana Demographic and Health Survey, 13-24

Gilmore, A., Tavakoly, B., Taylor, G. and Reed, H. (2013) 'Understanding tobacco industry pricing strategy and whether it undermines tobacco tax policy: the example of the UK cigarette market', Addiction 108(7): 1317-1326, https://doi.org/10.1111/add.12159

GlobalData (2019) GlobalData Report. Cigarettes in Ghana, 2019, retrieved April 5, 2020, from https://www.marketresearch.com/GlobalData-v3648/Cigarettes-Ghana-12493946/

Goodchild, M., Perucic, A. and Nargis, N. (2016) 'Modelling the impact of raising tobacco taxes on public health and finance', Bulletin of the World Health Organization, 94(4): 250-257, https://doi.org/10.2471/BLT.15.164707

— and Zheng, R. (2018) 'Early assessment of China's 2015 tobacco tax increase', Bulletin of the World Health Organization 96(7): 506-512

https://doi.org/10.2471/BLT.17.205989

Ho, L., Schafferer, C., Lee, J., Yeh, C. and Hsieh, C. (2018) 'Raising cigarette excise tax to reduce consumption in low-and middle-income countries of the Asia-Pacific region : a simulation of the anticipated health and taxation revenues impacts', BMC Public Health 18(1187)

IARC (2011) Effectiveness of Tax and Price Policies for Tobacco Control. IARC Handbooks on Tobacco Control (Vol. 14), retrieved from https://publications.iarc.fr/Book-AndReport-Series/larc-Handbooks-Of-Cancer-Prevention/Effectiveness-Of-Tax-And-PricePolicies-For-Tobacco-Control-2011

Jha, P. and Chaloupka, F. (2000) 'The economics of global tobacco control', British Medical Journal, 321(7257): 358-361, https://doi.org/10.1136/bmj.321.7257.358

Kostova, D., Tesche, J., Perucic, A., Yurekli, A. and Asma, S. (2013) 'Exploring the relationship between cigarette prices and smoking among adults: A cross-country study of low-and middle-income nations', Nicotine and Tobacco Research 16(SUPPLEMENT1): 10-15, https://doi.org/10.1093/ntr/ntt170

La Foucade, A., Gabriel, S., Scott, E., Metivier, C., Theodore, K., Cumberbatch, A., ... Lalta, S. (2018) 'Increased taxation on cigarettes in Grenada: potential effects on consumption and revenue', Pan American Journal of Public Health 42: 1-7, https://doi.org/10.26633/rpsp.2018.195

Levy, D. (2010) SimSmoke Tobacco Control Policy Simulation Model, retrieved 25 March 2020, from Georgetown University website: https://resources.cisnet.cancer.gov/registry/packages/simsmoke-georgetown/\#basics

Linegar, D. and van Walbeek, C. (2018) 'The effect of excise tax increases on cigarette prices in South Africa', Tobacco Control 27(1): 65-71, https://doi.org/10.1136/tobaccocontrol-2016-053340

Logo, D., Kyei-Faried, S., Oppong, F., Ae-Ngibise, K., Ansong, J., Amenyaglo, S., Ankrah, 
S., Singh, A. and Owusu-Dabo, E. (2020) 'Waterpipe use among the youth in Ghana: Lessons from the Global Youth Tobacco Survey (GYTS) 2017', Tobacco Induced Diseases 18: 47, https://doi.org/10.18332/tid/120937

MoH and GHS (2010) Needs Assessment for Implementation of the WHO Framework Convention on Tobacco Control in Ghana, retrieved from

https://www.ghanahealthservice.org/downloads/Needs_Assesment_for_Tobacco_Cont rol_In_Ghana.pdf

Nana, V. (2014) 'Tobacco taxation in West Africa: Overview issues and options for tobacco control', Consortium Pour La Recherche Economique et Sociale (CRES) 66(221): 1-15, retrieved from www.cres-sn.org

$\mathrm{NCl}$ and WHO (2017) National Cancer Institute and World Health Organization. The Economics of Tobacco and Tobacco Control Beyond Taxation: Monograph Presentation, retrieved from http://pubdocs.worldbank.org/en/856731488396350719/FJC-World-Bank-MonographPresentation-Feb-27-2017.pdf

(2016) The Economics of Tobacco and Tobacco Control, U.S. National Cancer Institute Tobacco Control Monograph 21., NIH Public (No. 16-CA-8029A), 688, retrieved from http://cancercontrol.cancer.gov/brp/tcrb/monographs/21/index.html

Nketiah-Amponsah, E., Afful-Mensah, G. and Ampaw, S. (2018) 'Determinants of cigarette smoking and smoking intensity among adult males in Ghana', BMC Public Health 18(1): 941-950

Owusu-Dabo, E., Lewis, S., McNeill, A., Anderson, S., Gilmore, A. and Britton, J. (2009) 'Smoking in Ghana: A review of tobacco industry activity', Tobacco Control 18(3): 206211, https://doi.org/10.1136/tc.2009.030601

Parliament of Ghana (2015) Excise Duty (Amendment) Act, 2015

Rodríguez-Iglesias, G., Schoj, V., Chaloupka, F., Champagne, B. and Gonzalez-Rozada, M. (2017) 'Analysis of cigarette demand in Argentina: the impact of price changes on consumption and government revenues', Salud Publica Mex 59(1): 95-101

Ross, H., Tesche, J. and Vellios, N. (2017) 'Undermining government tax policies : Common legal strategies employed by the tobacco industry in response to tobacco tax increases', Preventive Medicine 105: S19-S22, https://doi.org/10.1016/j.ypmed.2017.06.012

Singh, A., Owusu-Dabo, E., Dobbie, F., Mdege, N., McNeill, A., Britton, J. and Bauld, L. (2020) 'A situational analysis of tobacco control in Ghana: progress, opportunities and challenges', Journal of Global Health Reports 4: e2020015, https://doi.org/10.29392/001c.12260

TETSiM (2010) TETSiM Appendix: Mathematical Derivation of the Model5, pp. 2-5, retrieved from http://open.uct.ac.za/bitstream/handle/11427/2537/appendix_a.pdf?sequence=1\&isAllo wed $=y$

Tobacco Atlas (2018) Tobacco Taxes. Country Profile: Ghana, retrieved from 
https://tobaccoatlas.org/country/ghana/

VALD (2010) A Civil Society Shadow Report on Ghana's Implementation of the Framework Convention on Tobacco Control (FCTC), retrieved from https://www.fctc.org/wpcontent/uploads/2018/05/FCTC-implementation-Ghana-2010.pdf

van Walbeek, C. (2014) Raising Additional Government Revenues in Ghana by Raising the Excise Tax on Tobacco and Alcohol (English), WBG Global Tobacco Control Program Washington, D.C. : World Bank Group, retrieved from http://documents.worldbank.org/curated/en/133561561707742558/Raising-AdditionalGovernment-Revenues-in-Ghana-by-Raising-the-Excise-Tax-on-Tobacco-and-Alcohol

(2010) 'A simulation model to predict the fiscal and public health impact of a change in cigarette excise taxes', Tobacco Control 19(1)): 31-36, https://doi.org/10.1136/tc.2008.028779

Vellios, N., Ross, H. and Perucic, A. (2018) 'Trends in cigarette demand and supply in Africa', PLoS ONE 13(8): 1-13, https://doi.org/10.1371/journal.pone.0202467

Verguet, S., Gauvreau, C., Mishra, S., Maclennan, M., Murphy, S., Brouwer, E., ... Jamison, D. (2015) 'The consequences of tobacco tax on household health and finances in rich and poor smokers in China : an extended cost-eff ectiveness analysis', The Lancet 3(4): E206-E216, https://doi.org/10.1016/S2214-109X(15)70095-1

Wellington, E. (2017). Challenges of Implementation of the WHO Framework Convention on Tobacco Control (FCTC) - a case study of Ghana, Monash University, (22974806), retrieved from https://doi.org/10.4225/03/599a3bdd72b0d

WHO (2019) WHO report on the global tobacco epidemic, 2019. Country Profile, Ghana, https://www.who.int/tobacco/surveillance/policy/country_profile/gha.pdf?ua=1

(2018) The WHO Tobacco Tax Simulation Model WHO TaXSiM: User Guide, World Health Organisation, retrieved from https://apps.who.int/iris/bitstream/handle/10665/260177/WHO-NMH-PND-18.3-eng.pdf

(2010) WHO Technical Manual on Tobacco Tax Administration, World Health Organization, retrieved from https://www.who.int/tobacco/publications/tax_administration/en/

(2003) WHO Framework Convention on Tobacco Control (FCTC), World Health Organisation, World Health Organization, retrieved from http://www.who.int/tobacco/framework/WHO_FCTC_english.pdf

Wilkinson, A., Scollo, M., Wakefield, M., Spittal, M., Chaloupka, F. and Durkin, S. (2019) 'Smoking prevalence following tobacco tax increases in Australia between 2001 and 2017 : an interrupted time-series analysis', The Lancet Public Health 4(12): e618-e627, https://doi.org/10.1016/S2468-2667(19)30203-8

World Bank (2018a) Economics of tobacco taxation toolkit, World Bank Publications, retrieved from http://documents1.worldbank.org/curated/en/238861522243274209/pdf/124696REVISED-P154568-IDNTobaccoExciseAssessment.pdf 
- (2018b) Reducing Tobacco Use through Taxation in Trinidad and Tobago: Modelling the Long-term Health and Economic Impact, World Bank Group, retrieved from http://documents.worldbank.org/curated/en/253741542884254431/pdf/132339-WPPUBLIC-21-11-2018-12-29-57-WBGTobaccoTrinidadTobagoR.pdf

Zheng, R. and Huang, J. (2015) 'Would raising tobacco tax in China unfairly burden the poor ?', The Lancet Global Health 3(4): e181-e182, https://doi.org/10.1016/S2214109X(15)70100-2 